\title{
Contexts and Concerns for Sustainability of Cultural Heritage Sites of Bishnupur
}

\author{
Asmita BASU
}

\begin{abstract}
Conservation of heritage sites is considered to be a vital component of their management since they are irreplaceable resources for the tourism industry. The present generation of human beings needs to be aware of the benefits and challenges of preservation and management of the cultural resources and the heritages. The process of managing the heritages of local or national significance has gained importance over the years to an extent that it has attained the status of an individual academic discipline. In an attempt to address this issue related to Sustainability, some appropriate measures should be taken. In order to obtain sustainable development, different Strategic management principles can be used. Strategic Management relates to identification of the purpose as well as the plans and actions to achieve the purpose. This paper focuses on the benefits of application of the principles of Strategic Management for the sustainable development of heritage sites of the Bishnupur district in West Bengal, India. From this study it may be concluded that multi-disciplinary approach is the need of the hour. By the way of integrating the two varied disciplines of heritage management and strategic management, it will be possible to achieve sustainable development of the heritage sites.
\end{abstract}

Keywords: Strategic Management, Cultural Heritage, Sustainability.

\section{Introduction}

Heritage can be referred to as anything which a person wants to conserve or to collect and in due course of time pass onto the future generations (Howard 2003: 12). The process of managing the heritages of local or national significance has gained importance over the years to an extent that it has attained the status of an individual academic discipline. The study of heritage management primarily encompasses scientific and in depth learning of the various tangible and intangible heritages including ancient monuments, buildings, cultures, traditions, etc., which identifies the different elements needed to reconstruct the human past. It is a multi-disciplinary study and in recent times an integrated and holistic management approach is being considered as a vital method of pursuing this subject. Usually the core concept of management is regarded as the domain of trained professionals formally dealing with conservation management or related fields. The term heritage management has wider purview and can include the skills and expertise of the formally trained management 
professionals as well as the informal and traditional ways of managing such resources (Silva and Chapagain 2013: 10-11). With modern lifestyles ushering in an era of industrial growth and economic development, manifestations of heritage sites expressed in cultural forms are losing their traditional essence in a rapidly transforming world. At this crucial point, two very important aspects of the management principles, and namely - Sustainable development and Strategic management, having broader implications, can be coagulated with the traditional approaches of heritage management in order to build a strategic and sustainable framework.

While defining the factors behind the success of economic activity, we should be considering the economic and managerial point of view which sets the prime focus on the continuous supply of resources (Müller-Christ 2011: 8 -9). The typical scheme of resource use that has an objective to meet the human necessities simultaneously preserving the environment in order to protect the needs of future generations leads towards the concept of Sustainable development. Sustainability may be defined as the capacity to tolerate and the capability to keep in existence.

It has become a topic of global concern for the present generation in order to preserve and manage the natural resources and the heritages. The term 'sustainable management' has been used to encompass the concept of sustainability or the responsibility to maintain the existence and continued development for the natural and physical environment. In the business and corporate scenarios much has been learned over the years about how firms develop, acquire, and utilize resources to create sustainable competitive advantage. Thus, Sustainability has been a central concept of strategic management for a long time. Apart from the competitive business advantages, there are certain fundamental issues in competitive environments and in social concerns which raise a relatively new and unaddressed set of events in strategic management research and practice that leads to an opportunity to revisit our existing notions of sustainability.

Historic heritages need to be managed in a sustainable manner to meet the requirements of present and future generations and to avoid the adverse effects on the environment and cultural resources of different regions. Sustainable management may include promoting adaptive uses of heritage places. This paper aims to conduct a multi-faceted study to highlight the benefits of application of the principles of strategic management for the sustainability of heritage sites through a case study of the Bishnupur temple sites in West Bengal which come under the purview of the tentative list of World Heritage site (cf. ASI 2018). 


\section{Promotion and Sustainability of World Heritage site}

World Heritage symbolizes a strong sense of Brand in respect to tourism and heritage conservation, which is developed from the extraordinary values of heritage sites as well as their fascinating potentials to attract visitors. As far as the concept of brand goes, it represents a combination of product attributes with additional functional and non-functional values linked with the brand. Following this line of thought, World Heritage clearly manifests brand characteristics. Thus, the brand World Heritage can easily attract tourists and can create a brand image itself which will help its promotion.

The present generation of human beings needs to be aware of the benefits and challenges of preservation and management of the cultural resources and the heritages. With time we have come across fresh new evidences which indicate that the current ecological, economic and social trends are not sustainable. In the attempt to solve this issue the concept of Sustainable development has emerged in recent times. Sustainable development relates to a pattern of resource use that aims to meet human needs while preserving the environment so that these needs can be met not only in the present, but also for future generations. The term was first used by the Brundtland Commission in its report presented to the United Nations in 1987. The United Nations has defined sustainable development as meeting "the needs of the present without compromising the ability of the future generations to meet their own needs." According to this concept, a nation or a society should be able to satisfy its need--- social, economic and others without jeopardizing the interest of the future generations. Sustainability requires that human activity only uses nature's resources at a rate at which they can be replenished naturally. According to social scientists, "sustainable development requires an economy directed at improving the quality of life, decoupled from the consumed resources" (Schmuck and Schultz 2002: 6).

Usually, when we speak of Sustainability, environmental and ecological issues are highlighted. Some of the other important issues such as sustainable development in the economy, in society, and the ones regarding resources are often ignored. This generally results in an overall unsustainable development. The modern concept of sustainable development involves the three major points of view - economic, social and ecological ones (Munasinghe 1993: 2-3). These three dimensions are regarded as the triple bottom line which is generally used in evaluating the success of a development program or project. In order to have a sustainable result, we need to critically analyse each of these elements (Rogers, Jalal and Boyd 2008: 42). 
However, in the $21^{\text {st }}$ century, the global challenges are required to be dealt with at the macro- and strategic-management levels. One of the foremost of those challenges is how to strategically manage sustainable development. Strategy is implemented in order to ensure that long-term strategic goals are met which, in its turn, conforms to the designated path of sustainable development. Strategic management has gained tremendous importance at the enterprise level. As suggested by A. Kazmi, "An effective organizational strategy, therefore, is one that capitalizes on the opportunities through the use of strengths and neutralizes the threats by minimizing the impact of weaknesses, to achieve predetermined objective" (Kazmi 2011: 72-73).

In recent times, an integrated and holistic management approach is considered to be a significant method of conservation and sustainable use of cultural resources. While trying to blend the two disciplines-Heritage management and Strategic management, we need to answer the big question-How can we balance the contemporary needs of the local community and the wider society connected to the recent global concepts with the help of management principles and cultural resources? To find an answer to this question, we need to analyse the cultural resources in the light of strategic management principles in order to obtain overall sustainable development.

The temples of Bishnupur are part of tentative list of the World Heritage Sites. The historic background and features of the temples of Bishnupur make them worthy of becoming a World Heritage Site. It is of utmost importance that we consider the issues related to sustainability of such great historic and cultural assets.

\section{Bishnupur Temple sites}

\section{The region and its historical background}

Bishnupur is a city of temples located in the district of Bankura, West Bengal. Bishnupur was once the ancient capital of Malla Dynasty (the $16^{\text {th }}$ century AD). The name derived from the name of Lord Vishnu, since a large section of people belongs to the 'Vaishnava' sect. Modern town of Bishnupur has new faces representing urbanization, but its temples and religious fervour still dominate the town's psyche and recall its former status of a royal city. Historians say that 1000 places of worship existed throughout the entire town in the nineteenth century and even today we can see hundreds of them spread across in the different parts of the town, some beautifully preserved while the others in a dilapidated state (Figure 1). Additionally, the historians have specified that about nothing less than thirty of such shrines and temples belong to the seventeenth-eighteenth 


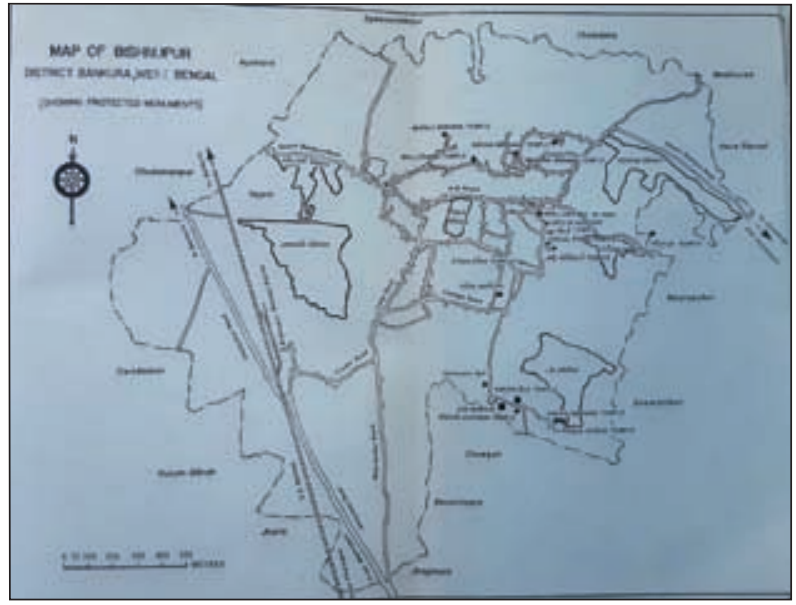

Figure 1. Map showing the temple sites in Bishnupur

century constructed by the Mallabhum kings who were the patrons of such magnificent Hindu temples housing metal images of Krishna and other deities of Vaishnavite order (Ring 1996: 137). The unique terracotta temples that we find in Bishnupur follow the traditional Bengal style temple architecture.

The basic structure is similar to that of a village hut with one or more chalas (roof) which resemble a typical Bengal folk hut (Nanda 2005: 64).

Out of the several architectural gems, some of the very popular temples are the Jor Bangla temple, Madan Mohan temple, the Shyam Rai temple, the Jor mandir group of temples, and Rasa-mancha.

\section{Jor Bangla Temple}

The twin hut shaped temple structure built of carved bricks represents typical Bengal type of folk architecture, joined together by a small tower on the top (Figure 2). This terracotta temple is intensely carved with terracotta plaques depict-

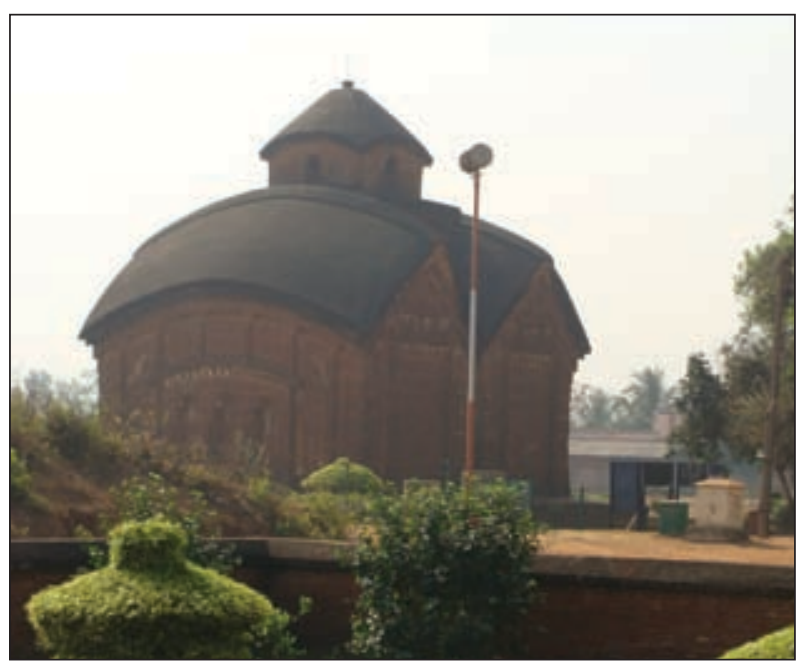

Figure 2. Jor Bangla Temple ing various scenes from the Puranasa, epics, Krishnalila, etc. It also consists of different scenes and episodes from contemporary life. It is considered as one of the best carved temple highlighting the historic heritage of Bishnupur. It may be dated back to $\mathrm{AD}$ 1734-35 (Biswas 1992: 15).

\section{Madan Mohan temple} It is a brick built temple with eka-ratna (single 


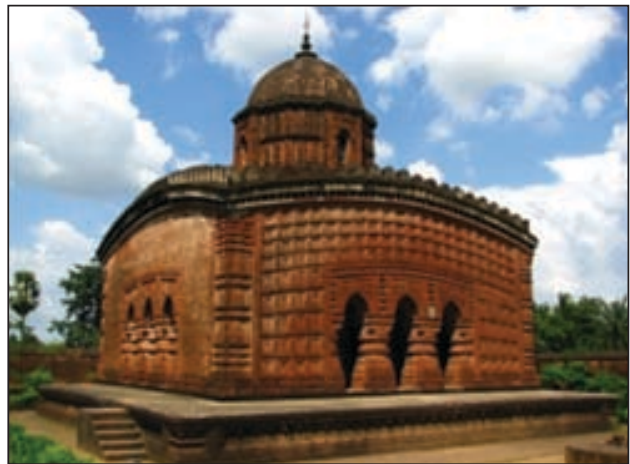

Figure 3. Madan Mohan Temple

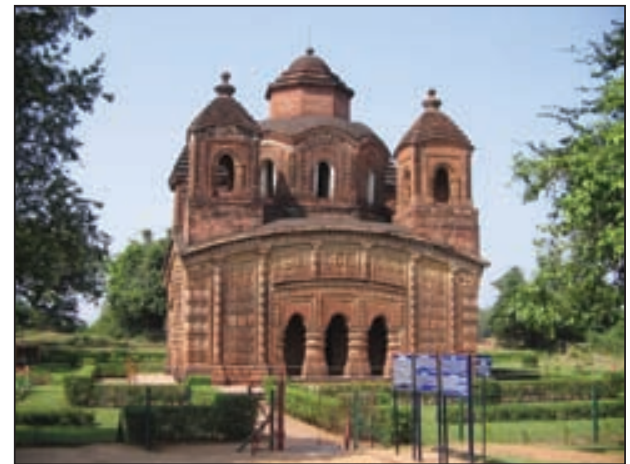

Figure 4. Shyamrai Temple

tower) shrine (Figure 3). According to inscriptional records, the Malla ruler, King Durjana Singha built this temple in 1694 AD. It has been constructed on a large plinth of laterite. The temple is much known for the exquisitely adorned walls and ornamental bricks. This temple consists of a single tower on a square sloping roof evidently symbolising the Bengal style of architecture. The facade contains magnificent carvings on terracotta plaques which depict epic stories and Puranic tales episodes from Krishnalila as main theme (Biswas 1992: 17)

\section{Shyam Rai temple}

This brick-built demonstrates the accomplishments of higher order. It is a Pancha-ratna temple being situated within the fort and consisting Pancha ratnas, i.e., five towers (Figure 4). The central tower itself is octagonal, surrounded by an octagonal corridor. The main facade of the temple comprises a narrative panel drawn after Ramayana and Krishnalila stories. It is thus most celebrated for its intricate terracotta ornamentations and the structural marvel. It is evident from the inscriptional records that King Raghunatha Singha constructed this temple in 1643 AD (Biswas 1992: 22-24).

\section{Jor mandir group of temples}

Three laterite temples, two big and one small are located near Lal -Bandh (water reservoir) constituting an entire temple complex which is known as JorMandir. The architectural pattern represents a combination of the prevalent local thatched hut-type and sikhara of North India. It is known from the foundation stone tablet on the northern-most temple that the temples were built in 1726 AD by the Malla King Gopal Singha. Out of the three temples belonging to Jor-Mandir group, two of the temples situated on the north and on the south are comparatively larger than the middle one (Biswas 1992: 18). 


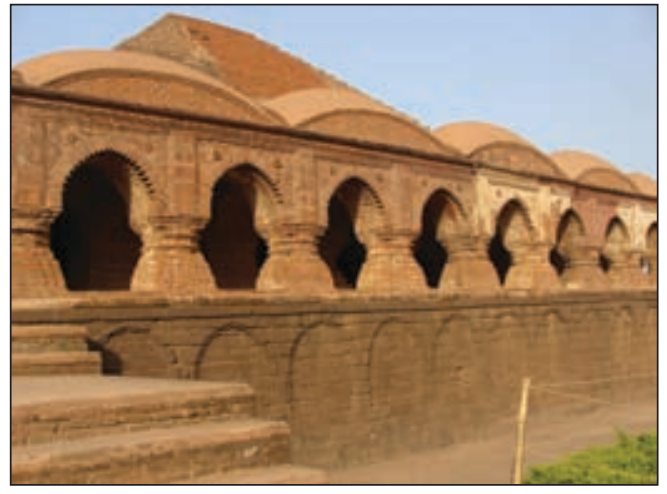

Figure 5. Rasmancha

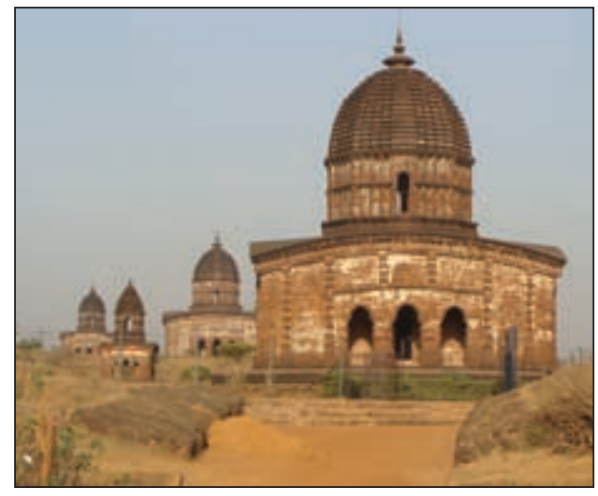

Figure 6. Jormandir Temple

\section{Rasa-mancha}

Built on a laterite plinth, it is one of the earliest structures at Bishnupur. Rasa mancha is an impressive square building formation with a small shrine in the centre. There are three-corridor galleries and vaulted roofs enclosing the central shrine. During Rasa festival, this structure is used for putting up idols from the nearby temples to carry out the rituals and festivities. It was built by Bir Hambir in $1600 \mathrm{AD}$ (Biswas 1992: 9).

\section{SWOT Analysis of the region}

SWOT analysis refers to a structured planning tool used to evaluate the Strengths, Weaknesses, Opportunities, and Threats usually involved in a project or in a business venture. This analysis can be carried out for a business, product, place or even a person. The analysis specifies the goal or objective of the business venture or project first, and then identifies the internal and external factors that are favourable and unfavourable to achieving it. To understand the potentialities of the region, at first we need to develop the basic framework. In order to do so, we take the help of the SWOT analysis technique as it is used by the business organizations. The SWOT analysis of Bishnupur temple sites is as follows:

From the analysis of the SWOT matrix we can easily identify the strengths and the weaknesses of the area of study. This will help us to make effective strategies and policies that are to be adopted in order to maximize the strengths and minimize the weaknesses. The other two segments of the matrix indicate the growing opportunities and the possible threats lying in the path of sustainable development. We need to take initiatives to develop the opportunities into strengths of the region and restrict the possible threats causing hindrance in the course of action. The SWOT analysis leads to the following points: ecological condition, economic condition and social condition. 


\section{Ecological condition}

The natural environment and ecology of the surrounding areas of the town of Bishnupur haven't been much favourable but the region has made sustainable and environmental use of natural resources such as land, climate and produce. It is a laterite belt belonging to Bankura district which forms a link between the plains of Bengal and the Chota Nagpur plateau. If we refer to history, we will find that the town planning of Bishnupur had been under a great influence of the traditional Vedic town planning system. It was a fortified city surrounded by a water filled moat. Apart from the other uses, this moat was used for collection of rain water. Due to the south to north sloping of the land, a number of Bandhs (reservoirs) were built to capture the flowing ground water during the rainy season (Sinha 2000: 376-381). Even in the present day we can find quite a few water tanks \& reservoirs in this area. The region has developed into an important centre for heritage tourism and the tourists are also attracted by the very essence of the natural environment (Dasgupta, Biswas and Mallik 2009).

\section{Economic Condition}

The economy is mainly based on agriculture and tourism. It lacks in the growth of industries. Although a small number of Textile industries and handicrafts are present, the economic development has not been too good. Bishnupur, which had a sustainable infrastructure, did not succeed in maintaining it at the time of conversion to the industrial mode (Sinha 2000: 376-381). Therefore, there is ample scope for development in this area, as identified in the 'opportunities' section of the SWOT matrix (Chart 1).

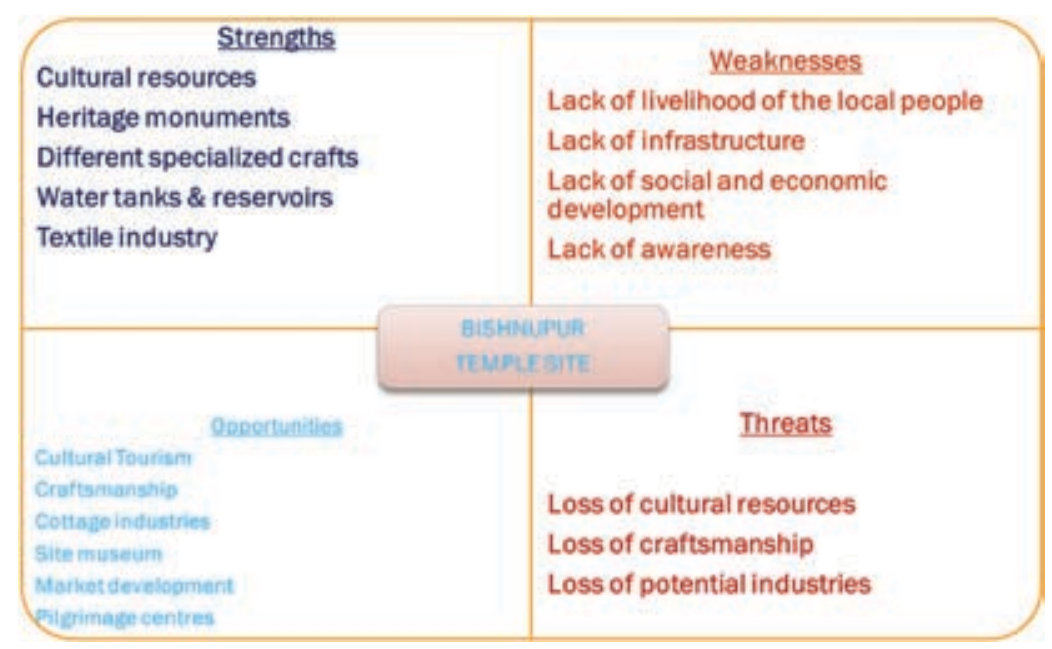

Chart 1: SWOT matrix for the Bishnupur temple site 


\section{Social condition}

Since this town boasts the royal legacy through the remaining architectural gems, it can be transformed into a greater cultural tourism centre. The local people need to be aware of their heritages and protect them especially those temples and monuments which have been abandoned and are in worn out condition.

\section{Need for strategic analysis}

Usually, organizations engage in strategic management in order to outperform those that do not use this principle. In the present scenario, strategic management principles help to attain an appropriate match between the internal and external environment which leads to a positive effect on the growth and development of the region. Strategic planning allows for: (1) development of long-term solutions that are based on an informed context and well developed management strategy; (2) reducing the risk arising from the unforeseen negative implications; (3) providing useful guidelines for focusing in detail on complex situations creating obstruction in the path of sustainable development.

A strategy is formulated with an intention to achieve a position in the market which will not only help the company to earn more profit as compared to its competitors but also help to sustain that position for a significant period of time (Sadler 2003: 13). This concept can be referred to as the sustainable competitive advantage.

Strategic management process can be viewed as a roadmap - a way of drawing the road within a specified time frame and space, with a view to determine and evaluate the viability of different routes to reach the ultimate destination (Varbanova 2013: 29). The strategic analysis of the region will help us in critically analysing the key factors to be considered for attaining sustainable competitive advantage. In order to design appropriate strategy, we need to understand the core areas which require attention. The strengths and opportunities which have been identified in Chart 1 indicate the competitive advantage of this region. On the other hand, the weaknesses and threats will help to identify the challenges in the pathway of achieving sustainability. This preliminary analysis will focus on the future strategic plans and course of action.

\section{Conclusion}

Thus, we may conclude from the analysis above that cohesion between the two disciplines, and namely Heritage management and Strategic management will lead to the sustainable development of the heritage sites. In addition to the tradition- 
al methods for preserving the heritage sites, this multi-disciplinary approach will not only help to sustain the cultural heritage but also generate revenues by proving a platform for the indigenous skill and handicrafts. This will also help to achieve economic growth and development of the region. Unprotected monuments and heritages in danger can be revived with the help of building a bridge with the corporates. Financial support and infrastructure development could be the key support obtained from the corporates for the sustainability of the heritage sites.

\section{References}

ASI (2018) = Archaeological Survey of India - Kolkata Circle. Bankura. Online: www. asikolkata.in/bankura.aspx.

Biswas, S.S. (1992). Bishnupur. Delhi: Archaeological Survey of India.

Dasgupta, S., R. Biswas and G.K. Mallik (2009). Heritage Tourism: An Anthropological Journey to Bishnupur. New Delhi: Mittal Publications.

Howard, P. (2003). Heritage: management, interpretation, identity. London-New York: Continuum.

Kazmi, A. (2011). Strategic Management and Business Policy. New Delhi: Tata McGraw Hill Education.

Müller-Christ, G. (2011). Sustainable management: coping with the dilemmas of resourceoriented management. Berlin: Springer.

Munasinghe, M. (1993). Environmental economics and sustainable development. Washington, D.C.: World Bank environment paper, no.3.

Nanda, J.N. (2005). Bengal: The Unique State. New Delhi: Concept Publishing Company.

Ring, T., N. Watson and P. Schellinger (eds) (1996). Asia and Oceania: International Dictionary of Historic Places. New York: Routledge.

Rogers, P.P., K.F. Jalal and J.A. Boyd (2008). An introduction to sustainable development. London: Glen Educational Foundation.

Sadler, P. (2003). Strategic Management. London: Kogan Page.

Schmuck, P. and W.P. Schultz (eds) (2002). Psychology of Sustainable Development. Boston: Kluwer Academic Publishers.

Silva, K.D. and N.K. Chapagain (eds) (2013). Asian heritage management: Contexts, concerns, and prospects. New York: Routledge.

Sinha, S. (2000). "Learning from precedents: Environmental tradition of an Indian city". In: K. Steemers and S. Yannas (eds), Architecture, City, Environment: Proceedings of PLEA 2000. Cambridge: James \& James.

Varbanova, L. (2013). Strategic Management in the Arts. New York, London: Routledge. 


\section{Contextele și preocupările pentru sustenabilitatea siturilor patrimoniului cultural din Bishnupur}

\section{Rezumat}

Conservarea siturilor de patrimoniu este considerată o componentă vitală a gestionării lor, deoarece acestea sunt resurse de neînlocuit pentru industria turistică. E nevoie ca generațiile actuale să fie conștiente de beneficiile și provocările de conservare și gestionare a resurselor culturale și a patrimoniului. Procesul de gestionare a patrimoniului cu semnificaţie locală sau naţională a căpătat importanță de-a lungul anilor într-o măsură în care a atins statutul unei discipline academice autonome. În încercarea de a aborda această problemă legată de durabilitate, ar trebui luate unele măsuri adecvate. Pentru a obține o dezvoltare durabilă, pot fi utilizate diferite principii de management strategic. Managementul strategic se referă la identificarea scopului, precum și la planurile și acțiunile de realizare a scopului. Această lucrare se concentrează pe beneficiile aplicării principiilor managementului strategic pentru dezvoltarea durabilă a siturilor de patrimoniu din districtul Bishnupur din Bengalul de Vest, India. Din acest studiu se poate concluziona că abordarea multidisciplinară este o necesitate actuală. Prin integrarea celor două discipline variate de gestionare a patrimoniului şi gestionare strategică va fi posibilă realizarea dezvoltării durabile a siturilor de patrimoniu.

Cuvinte-cheie: management strategic, patrimoniu cultural, durabilitate.

Asmita Basu, Army Institute of Management, Kolkata, India, e-mail: asmita.basu2011@gmail.com 